\section{Til å bli oppstemt av!}

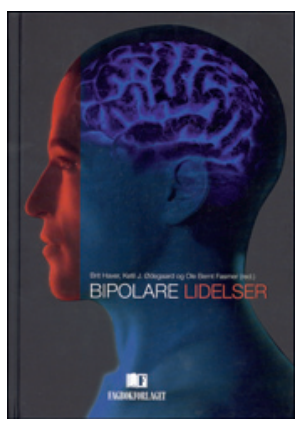

Brit Haver, Ketil J. Ødegård,

Ole Bernt Fasmer, red.

Bipolare lidelser

487 s, tab, ill. Bergen: Fagbokforlaget, 2012.

Pris NOK 679

ISBN 978-82-450-0585-1

Redaktører, forfattere og forlag er å gratulere med dette verdifulle bidraget til norsk psykiatrisk faglitteratur. Bipolare lidelser, diagnostikk, utredning, behandling og komorbide lidelser presenteres av høyt kvalifiserte spesialister med vekt på oppdatert og evidensbasert kunnskap. Lærerike innspill fra pasienter og pårørende bidrar til å gjøre fremstillingen levende og praksisnær. Ifølge redaktørene er dette «først og fremst en lærebok og oppslagsbok for fagfolk». Etter mitt syn er den for omfattende for allmennleger, mens pasienter med bipolare lidelser og deres pårørende har mye å hente. Det skyldes ikke minst et gjennomført ledig og uakademisk språk som gjør boken lett tilgjengelig. En delikat layout og god bruk av rammer og vignetter øker også leservennligheten.

Med tanke på at boken bør komme i nye utgaver, angir jeg noen muligheter for forbedringer. Boken er ensidig nevrobiologisk preget, og det kan like gjerne stå i forordet fremfor på side 426: «Sykdommen skyldes biologiske forandringer i hjernen som påvirker stemningsleie og en rekke andre funksjoner.» I så måte er dette en bok av leger for leger, og jeg savner en drøfting av plassen til andre profesjoner i psykiatriske team ved bipolare lidelser. Min tyngste innvending er i samme gate, her er intet kapittel om hvordan omsorgen for bipolare pasienter skal organiseres i dagens norske helsevern. Skal den skje på spesialistnivå? Bør vi ha bipolar-poliklinikker? Hva kan fastlegene gjøre? Verken distriktspsykiatriske poliklinikker (DPS) eller samhandling omtales i teksten, og fastlegene får én side (s. 437). Mangelen på sosiale og psykologiske synspunkter er desto mer påfallende siden de er så viktige i pasientog pårørendeinnspillene. Marius Viseths kapittel om ulike bedringsperspektiver er et hederlig unntak, og nye utgaver bør ha mer slikt stoff.

Mindre alvorlig er det at diagnostiske kriterier og medikamentell behandling omtales mange ganger. I forordet heter det: «Gjentakelser kan forekomme, da dette kan være berettiget i forbindelse med ulike aspekter av sykdommen.» Den berettigelsen er ikke oppfylt, og strammere redigering vil gi økt leservennlighet og kortere bok. Kapitlet om personlighet og temperament er ikke oppdatert til dagens kunnskapsnivå, og mange steder mangler definisjoner av nøkkelbegreper, som «kognitiv svikt». Problemet med økologisk validitet ved nevropsykologiske tester er ikke nevnt. Omtalen av kreativitet, bipolaritet og rus er preget av vestlandspietisme. Det underliggende verdisynet er at lange, sunne, kjedelige liv er bedre en korte, stormfulle og kreative. «It Ain’t Necessarily So», for å si det med Sportin' Life.

La ikke disse innvendingene forkludre at dette er en veldig god bok primært beregnet på spesialisthelsetjenesten. De som arbeider med angstlidelser, rus og alderspsykiatri bør komme med tilsvarende bøker.

Alv A. Dahl

Oslo universitetssykehus, Radiumhospitalet

Oppgitte interessekonflikter: Forfatteren har også gitt ut bok på Fagbokforlaget i januar 2012.

\section{En historie om et fosterbarn}

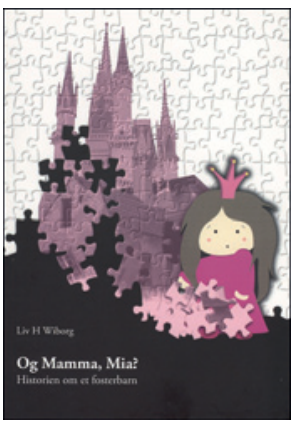

Liv H. Wiborg

Og Mamma, Mia?

Historien om et fosterbarn. $159 \mathrm{~s}$ Oslo: Kolofon forlag, 2011. Pris NOK 250

ISBN 978-82-300-0864-5

Boken er beregnet for alle som ønsker et innblikk i hvordan det kan være å bli, og leve som, fosterbarn. Den er også beregnet på barn, og kan leses av barn i 10-12 års alder og leses høyt for småskolebarn. Boken vil gi lite ny kunnskap for fagfolk som jobber opp mot barnevernet.

Og Mamma, Mia? er skrevet som en kronologisk historie hvor vi følger Mia fra barnevernet overtar omsorgen for henne til hun adopteres av fosterforeldrene sine. Historien er bygd opp som en skjønnlitterær roman, men med stopp ved overganger i den formelle i saksgangen i barnevernet, og med eksempler på problemer og utfordringer som barn, hvor barnevernet må overta omsorgen, kan møte. Språket er lettfattelig og teksten ganske kort og tilpasset barn, noe som gjør den rask å lese for voksne.

Den skjønnlitterære formen gjør at boken berører følelsesmessig og blir engasjerende, men den er for kortfattet som en roman som skal fortelle om en oppvekst med mange utfordringer. Grunnen er at forfatteren kun beskriver glimt av barnets følelser og opplevelser uten at disse følges over tid. I den forbindelse virker det også litt forvirrende at selv om saken går over flere år, og Mia logisk sett blir eldre, er det ingen merkbar aldersmessig utvikling hos hovedpersonen i fortellingen.

Det at boken ikke er skrevet som en fullstendig roman giør at det er mest aktuelt å lese den dersom man har en grunn til å ville bli mer kjent med barnevernet og barnevernsbarn. Boken kan egne seg godt dersom noen i slekten eller omgangskretsen skal bli eller er fosterforeldre, eller dersom man på annen måte blir kjent med noen som er fosterbarn. Det kan være lett for barn å bli opphengt i Mias historie, noe som kan gjøre det vanskelig å se det generelle i denne historien dersom de har en annen virkelig historie å forholde seg til. Jeg kan likevel anbefale boken i slike situasjoner. Den kan gi et fint utgangspunkt for samtaler også om den virkelige situasjonen.

Saksgangen beskrives riktig, og de følelsene og reaksjonene som beskrives hos barnet, er kjente og realistiske, men ingen av delene berøres grundig nok til at boken kan betraktes som lærebok.

\section{Mia Cathrine Myhre}

Nasjonalt kunnskapssenter om vold og traumatisk stress 